NISTIR 7718

\title{
Thirteenth Annual Report on Federal Agency Use of Voluntary Consensus Standards and Conformity Assessment
}

\author{
Mary F. Donaldson \\ Standards Coordination and Conformity Group \\ Standards Services Division \\ Technology Services
}

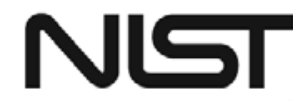

National Institute of Standards and Technology 
NISTIR 7718

\section{Thirteenth Annual Report on Federal Agency Use of Voluntary Consensus Standards and Conformity Assessment}

Mary F. Donaldson

Standards Coordination and Conformity Group

Standards Services Division

Technology Services

August 2010

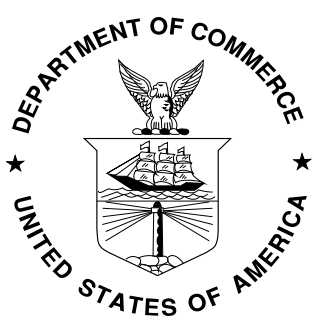

U.S. Department of Commerce

Gary Locke, Secretary

National Institute of Standards and Technology Patrick D. Gallagher, Director 


\section{Table of Contents}

1.0 - Executive Summary ..................................................................................................... 2

2.0 - Overview and Scope................................................................................................... 3

3.0 - Federal Agency Use of Standards.............................................................................. 3

3.1 - Government-Unique Standards Used in Lieu of Voluntary Consensus

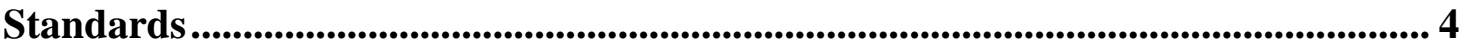

3.2 - New Uses of Voluntary Consensus Standards (VCSs) By Federal Agencies.. 5

3.3 - Current Agency Reporting on Voluntary Consensus Standards Substituted

for Government-Unique Standards................................................................................ 5

4.0 - Federal Participation in Private Sector Standards Activities................................. 6

4.1 - Participation Data for FY 2009 ................................................................................ 6

5.0 - Federal Agency Conformity Assessment Activities .................................................. 7

6.0 - Evaluation of the Effectiveness of OMB Circular A-119 ........................................ 9

7.0 - The Interagency Committee on Standards Policy (ICSP)....................................... 10

8.0 - Success Stories: Examples from Federal Agencies ................................................. 10

9.0 - Summary and Conclusions .......................................................................................... 12

Appendix A - FY 2009 List of Reporting Federal Agencies ........................................... 13

Appendix B - FY 2009 Federal Agency Information on Participation/Adoption of

Voluntary Standards Activities Required by OMB Circular A-119............................ 14

Appendix C - FY 2009 Government-Unique Standards Used in Lieu of Voluntary

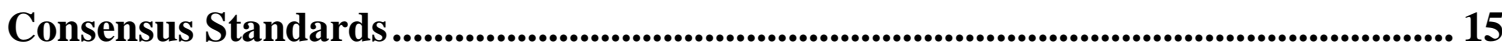




\section{Summary Report on Federal Agency Use of Private-Sector Standards and Conformity Assessment Activities for Fiscal Year 2009}

\section{0 - Executive Summary}

The U.S. Department of Commerce presents this summary report for the Office of Management and Budget (OMB) in compliance with OMB Circular A-119 and Public Law 104-113, the National Technology Transfer and Advancement Act (NTTAA). As required by Section 9 of the Circular, this report, prepared by the National Institute of Standards and Technology (NIST), describes activities related to the use of voluntary consensus standards (VCSs) by 25 Federal agencies during fiscal year (FY) 2009.

In keeping with the requirements of the NTTAA, Federal agencies continue to look to voluntary consensus standards in support of their regulatory and procurement activities. NIST, through its Standards Incorporated by Reference database, independently tracks governmental use of private-sector standards. As of the date of this report, NIST has identified over 8400 citations of standards incorporated by reference in regulatory documents - more than 80 percent of these standards were developed by the private sector. Available online at http://standards.gov/sibr/query/index.cfm, this interactive database illustrates the extensive use of voluntary standards throughout the U.S. Government.

For Fiscal Year 2009, only one agency, the Department of Labor, promulgated a government unique standard in lieu of a VCS, bringing the total number of such reported standards to 46. Although government-unique, the new standard actually uses nine voluntary consensus standards as a basis for the single rule. Furthermore, for FY 2009, Federal agencies reported 520 new uses of VCSs. The continued adoption of significant numbers of VCSs and the low rate of development of new government-unique standards in lieu of VCSs illustrates the NTTAA's success in encouraging agencies to look first to voluntary consensus standards to meet their regulatory, procurement, and conformity assessment needs.

Agencies reported that 3316 personnel participated in a total of 528 standards-developing organizations during FY 2009. While not all time highs, these continued high levels of Federal engagement illustrate a sustained commitment of the U.S. Government to the activities of the voluntary consensus standards system.

The benefits of this engagement are reflected in the reports for FY 2009, which show that the Federal investment in voluntary standards development helps to provide sound technological underpinning to standards, speeds the standards development process, and enables the adoption of VCSs to support agency missions. Furthermore, adoption of VCSs for Federal agency use provides cost savings to Federal agencies, the Nation's businesses, and the taxpayer through reduced injuries and deaths, increased transactional efficiencies, reduced administrative burdens, and lower costs of products and services. 
For their FY 2009 reporting, several agencies provided illustrations of benefits realized from the adoption of and participation in the development of voluntary consensus standards. The Department of Energy's (DOE's) Savannah River Site transitioned to national codes and standards from site specific standards, resulting in the retirement of over 700 site specific guides and standards. The DOE also achieved improved cost efficiencies from participation in the development of the American Glovebox Society Standard, "Standard for Practice for the Design and Fabrication of Nuclear Application Gloveboxes,” a standard which established common requirements for gloveboxes that are used not only in various DOE facilities but are found in pharmaceutical and biological laboratory facilities as well.

Additionally, the Department of Health and Human Service's Substance Abuse and Mental Health Service Administration (SAMHSA) leveraged its staff resources by engaging in the development of voluntary consensus Electronic Health Records (EHR) standards within Health Level 7 and ANSI's Health IT Standards Panel (HITSP). This participation allows SAMSHA to benefit from the wide range of expertise among standards development participants. The resulting EHR standards enhance uniformity across the public and private sectors, improve efficiency of data reporting and accountability, support improvements in clinical care and enable more effective coordination of care between heath care providers and participants.

As a last example, the Nuclear Regulatory Commission (NRC) worked with the American Nuclear Society and the American Society of Mechanical Engineers to develop a joint standard on quality of probabilistic risk assessment (PRA) for nuclear power plants. This achievement was a result of over 10 years of work during which the NRC staff contributed their knowledge to the consensus standard development effort. The result was a single standard providing consistent guidance throughout the industry. These few examples help to illustrate the various ways that the U.S. Government and the taxpayer derive benefits from the development, adoption, and use of voluntary consensus standards.

\section{0 - Overview and Scope}

NIST formulated this report based on input submitted to NIST by 25 Federal agencies in fulfillment of the requirements of OMB Circular A-119 and the reporting requirements of Section 12 (d)(3) of the NTTAA. The report describes Federal agency activities related to the use of private-sector standards in regulation, procurement, and conformity assessment during FY 2009. A list of reporting agencies is in Appendix A.

\section{0 - Federal Agency Use of Standards}

The OMB Circular requires that Federal agencies use voluntary consensus standards in lieu of government-unique standards in their regulatory and procurement activities. However, a Federal agency is given the discretion to decide whether to use existing voluntary consensus standards if the agency determines that use of such standards would either be inconsistent with applicable laws or otherwise impractical. The Circular also 
directs agencies to establish a process for continuing review of their use of standards for purposes of updating such use, including substitution of private-sector standards for government-unique standards wherever possible.

\section{1 - Government-Unique Standards Used in Lieu of Voluntary Consensus Standards}

The OMB Circular requires that agencies report their use of standards on either a "categorical" or a "transactional” basis. Those agencies that report on a categorical basis are not required to list each instance that a government-unique standard is used in lieu of a private-sector standard in procurement actions. However, such agencies are required to have a system in place to ensure that government-unique standards are developed only when suitable private-sector standards are not available for use. At present, only the Department of Defense and the National Aeronautics and Space Administration (NASA) consistently report on a categorical basis. For all agencies, in those cases when government-unique standards are required because private-sector standards do not exist, use of the government-unique standard is not subject to reporting.

Table 3.1 illustrates the cumulative number of government-unique standards (that is, the total number broken down by year and by agency) used in lieu of private-sector standards since FY 1997, as well as the number of government-unique standards introduced and discontinued in each fiscal year. During FY 2009, one Federal agency, the Department of Labor, reported developing a standard for vertical tandem lifts used in longshoring and marine terminals. Although government-unique, this standard incorporates nine voluntary consensus standards into a single rule.

\begin{tabular}{|l|c|c|c|c|c|c|c|c|c|c|c|c|c|}
\hline \multicolumn{1}{|l|}{ Table 3.1 Government-unique Standards Used in Lieu of Private Sector Standards Statistics } \\
\hline Agency & $\mathbf{1 9 9 7}$ & $\mathbf{1 9 9 8}$ & $\mathbf{1 9 9 9}$ & $\mathbf{2 0 0 0}$ & $\mathbf{2 0 0 1}$ & $\mathbf{2 0 0 2}$ & $\mathbf{2 0 0 3}$ & $\mathbf{2 0 0 4}$ & $\mathbf{2 0 0 5}$ & $\mathbf{2 0 0 6}$ & $\mathbf{2 0 0 7}$ & $\mathbf{2 0 0 8}$ & $\mathbf{2 0 0 9}$ \\
\hline USDA & & & & & & & & & 1 & 1 & 1 & 1 & 1 \\
\hline HHS & 3 & 3 & 3 & 3 & 3 & 3 & 3 & 2 & 2 & 4 & 4 & 1 & 1 \\
\hline HUD & & & & 2 & 2 & 2 & 2 & 2 & 2 & 2 & 2 & 2 & 2 \\
\hline DOL & & & & & 1 & 2 & 4 & 5 & 5 & 6 & 8 & 8 & 9 \\
\hline DOT & 1 & 2 & 2 & 2 & 2 & 3 & 3 & 3 & 3 & 3 & 3 & 3 & 3 \\
\hline EPA & & 3 & 28 & 29 & 40 & 45 & 50 & 50 & 50 & 50 & 23 & 23 & 23 \\
\hline GSA & & & & 3 & 2 & 2 & 3 & 2 & 2 & 3 & 3 & 3 & 3 \\
\hline NARA & & & & 1 & 1 & 1 & 1 & 1 & 1 & 1 & 1 & 1 & 1 \\
\hline CPSC & & & & 1 & 1 & 1 & 2 & 2 & 2 & 2 & 2 & 2 & 2 \\
\hline GPO & & & & 4 & 4 & 4 & 4 & 4 & & & & & \\
\hline ACCESS & & & & & & & & & & 1 & 1 & 1 & 1 \\
\hline New Uses & 4 & 4 & 25 & 12 & 12 & 7 & 9 & 2 & 2 & 5 & 2 & 0 & 1 \\
\hline Discontinued & & & & & 1 & & & 3 & 4 & & 27 & 3 & \\
\hline Total In Use & $\mathbf{4}$ & $\mathbf{8}$ & $\mathbf{3 3}$ & $\mathbf{4 5}$ & $\mathbf{5 6}$ & $\mathbf{6 3}$ & $\mathbf{7 2}$ & $\mathbf{7 1}$ & $\mathbf{6 8}$ & $\mathbf{7 3}$ & $\mathbf{4 8}$ & $\mathbf{4 5}$ & $\mathbf{4 6}$ \\
\hline
\end{tabular}


Appendix C lists the government-unique standard(s) used in lieu of voluntary consensus standards for FY 2009. For a complete listing of the government-unique standards used in lieu of voluntary consensus standards and the justifications from FY 1997 through FY 2009, see NIST's Standards website at http://standards.gov/NTTAA/agency/index.cfm.

\section{2 - New Uses of Voluntary Consensus Standards (VCSs) By Federal Agencies}

For FY 2009, Federal agencies reported the adoption of 363 new voluntary consensus standards. Five agencies - the Environmental Protection Agency and the Departments of Energy, Defense, Homeland Security, and Health and Human Services-accounted for 97 percent of the reported new uses.

\section{3 - Current Agency Reporting on Voluntary Consensus Standards Substituted for Government-Unique Standards}

Federal agencies also report annually on the number of voluntary consensus standards that they have substituted for government-unique standards during the year. Figure 3.3 illustrates the substitutions for each year since FY 1998. In FY 2009, Federal agencies substituted 112 voluntary consensus standards for government-unique standards. ${ }^{1}$ All of these substitutions were within the Department of Defense.

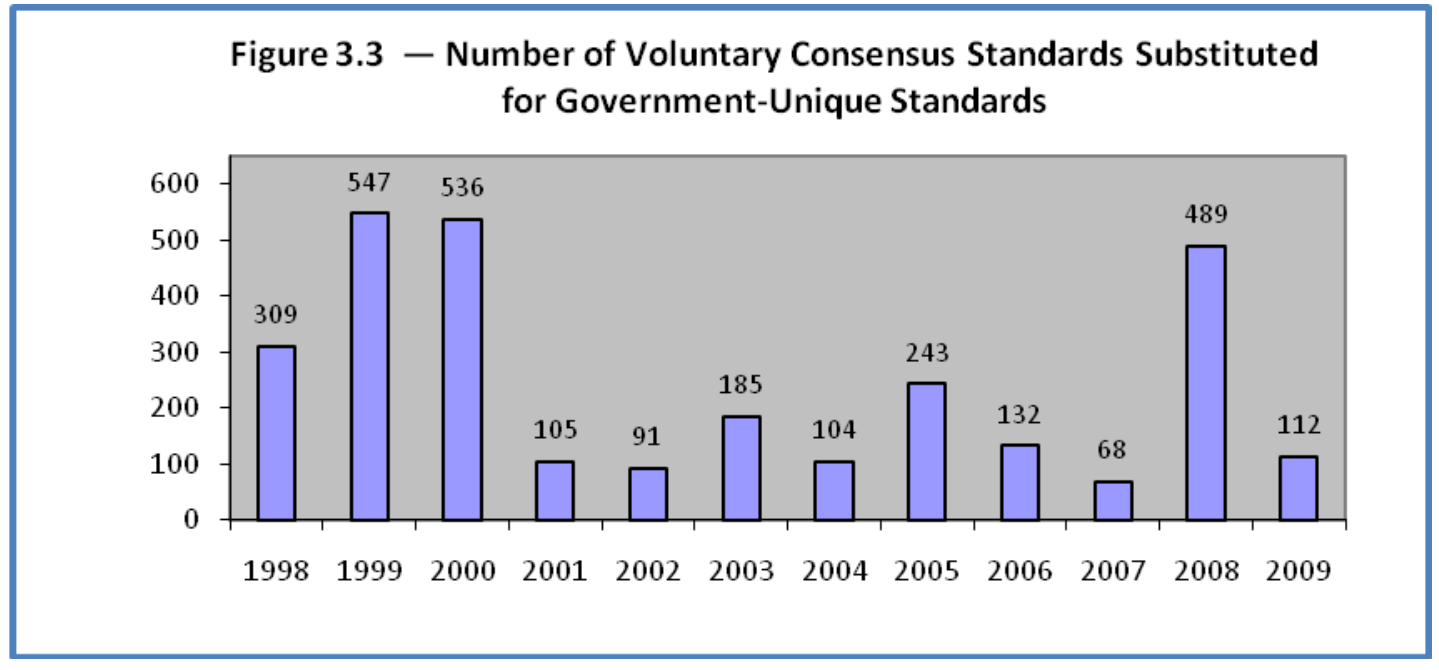

\footnotetext{
${ }^{1}$ Government-unique standards being substituted include the universe of government-unique standards, i.e., those in use prior to the implementation of NTTAA reporting, those that were not "in lieu of VCSs"; and those that were in lieu of VCSs. Since NIST began collecting data, there have been 3071 reported substitutions of VCSs for governmentunique standards across agencies. While we do not know the entire universe of government-unique standards, we know from published sources that the Department of Defense - the largest user of such standards — still uses over 20,000 government-unique standards, counting military, Federal, and NATO specifications, and as of FY 2006 was using more than 9,200 private-sector standards. The Department of Defense adopted 7,400 private-sector standards before 1997.
} 


\section{0 - Federal Participation in Private-Sector Standards Activities}

OMB Circular A-119 states that Federal agencies "must consult with voluntary consensus standards bodies, both domestic and international, and must participate with such bodies in the development of voluntary consensus standards when consultation and participation is in the public interest and is compatible with their missions, authorities, priorities, and budget resources." The Circular goes on to declare that "agency support provided to a voluntary consensus standards activity must be limited to that which clearly furthers agency and departmental missions, authorities, priorities, and is consistent with budget resources.”

\section{1 - Participation Data for FY 2009}

In FY 2009, agencies reported participation in 528 private-sector standards bodies compared to 534 in FY 2008, which was the all time high (see Figure 4.1a). The list of organizations includes voluntary consensus standards developers accredited by the American National Standards Institute (ANSI), other (non-ANSI-accredited) standards developers, industry and trade associations, international organizations, and consortia.

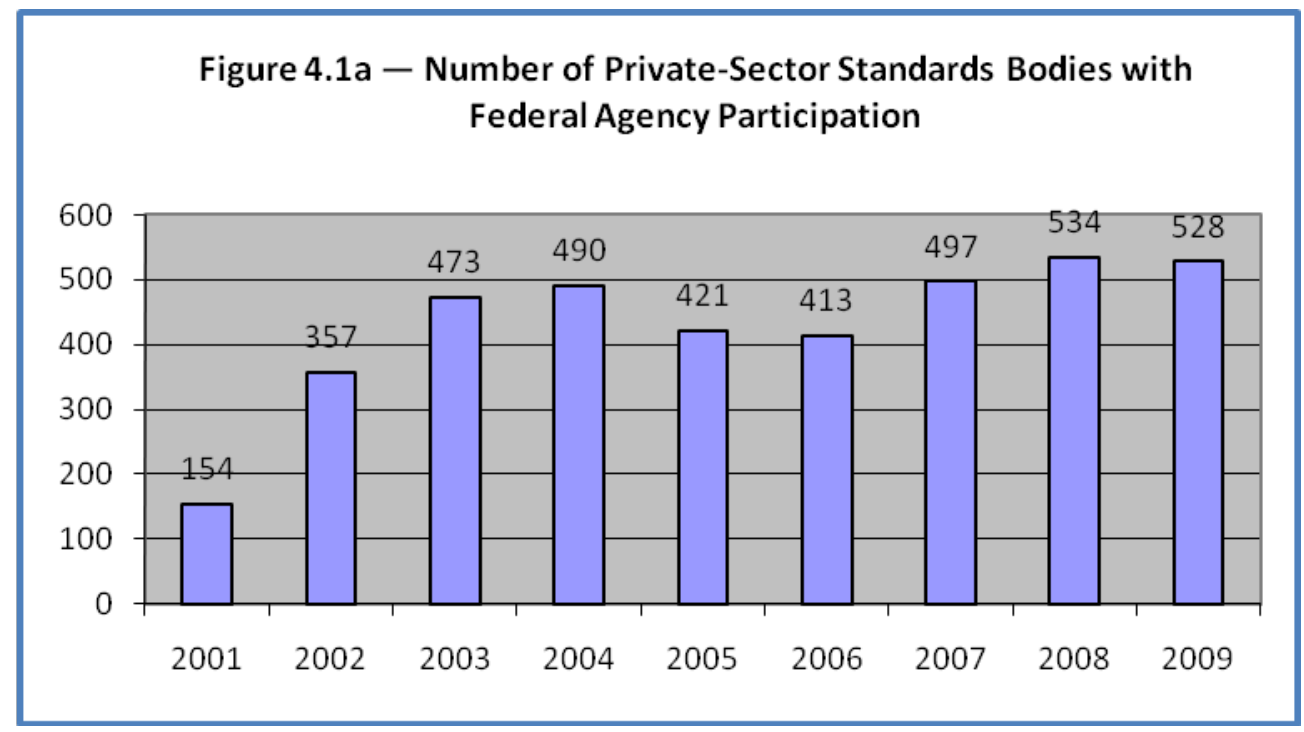

Federal agencies are also required by OMB to report the number of Federal employees who participate in private-sector standards body activities. This includes not only those who serve on technical standards development committees, subcommittees, or workgroups, but also those who participate in management activities, annual meetings, or seminars. In FY 2009, Federal agencies reported that 3,316 employees participated in private-sector standards body activities. Furthermore, this figure represents an increase from the previous year, with participation continuing to remain above the annual average of 2,785 for reporting agencies. The Department of Health and Human Services experienced the majority of this increase $(+296)$ bringing to 1,150 the number of their employees participating in voluntary consensus standards body activities. Figure 4.1b 
illustrates total Federal employee participation in private-sector standards body activities since FY 1998. Data detailing FY 2009 participation for each agency is provided in Appendix B.

A complete listing of the standards-developing organizations in which Federal agencies participated can be viewed in the extended appendices to this report, located at http://standards.gov/NTTAA/agency/index.cfm.

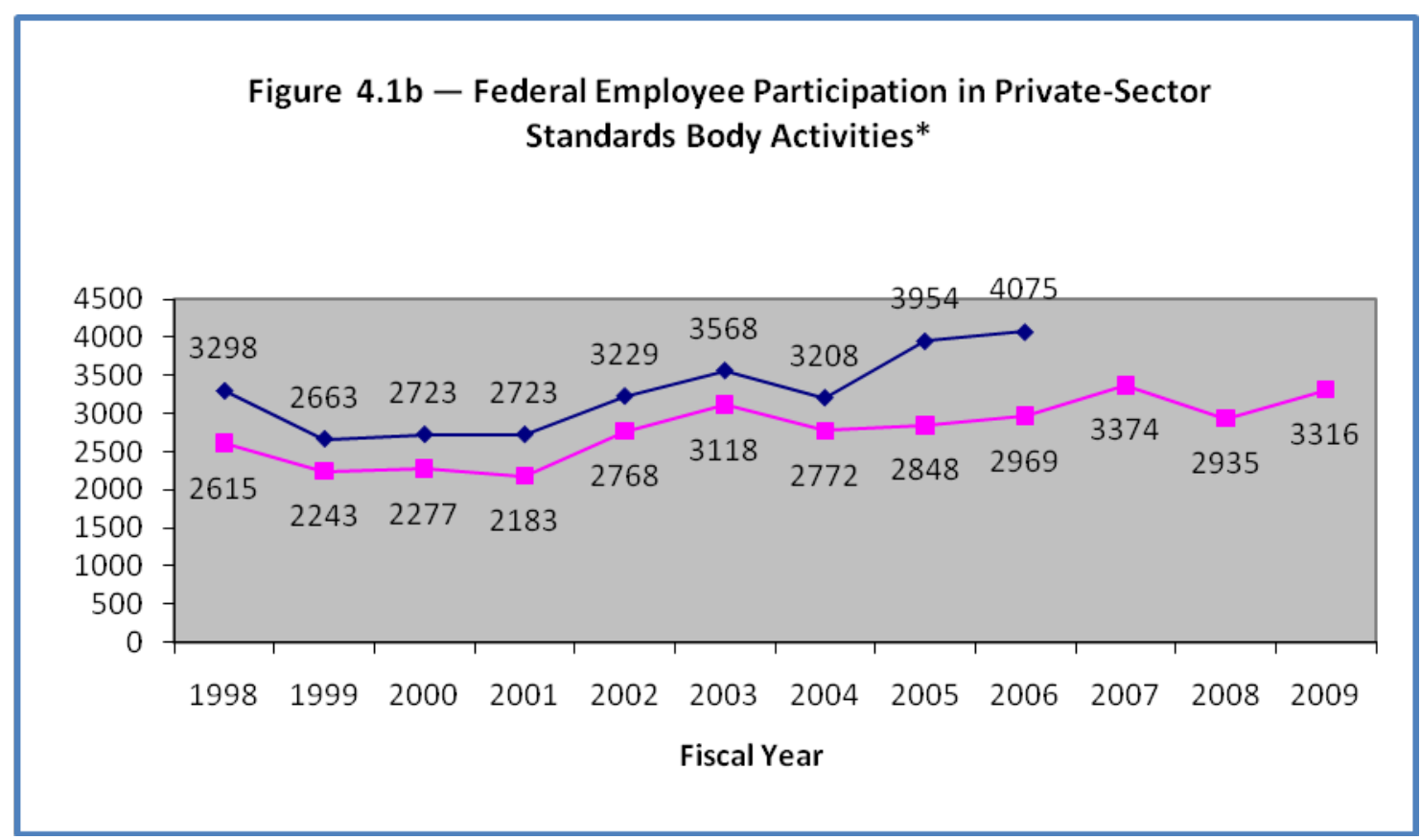

* The upper series includes Department of Defense participation data prior to 2007, while the lower series excludes Department of Defense participation.

\section{0 - Federal Agency Conformity Assessment Activities}

The NTTAA requires NIST to coordinate Federal, State, and local government standards and conformity assessment activities with those of the private sector, with the goal of eliminating unnecessary duplication and complexity in the development and promulgation of conformity assessment requirements and measures. Federal conformity assessment activities are a means of providing assurance that the products and services regulated or procured by Federal agencies have the required characteristics and/or perform in a specified manner. Agency conformity assessment procedures may include sampling and testing; inspection; accreditation; certification; licensing; product listing; the submission to an agency of manufacturing, operational, and related data for review; manufacturer self-declaration of conformity to agency requirements; mandatory labeling and advertising requirements; establishment of national requirements, which are then adopted/enforced at the State and local government levels; issuance of regulatory guidelines; pre-marketing approval requirements; post-marketing monitoring requirements; and conducting environmental impact assessments. NIST publishes a 
number of directories and reports on conformity assessment-related issues and maintains a website at http://www.nist.gov/ts/ssd/index.cfm that provides a "one-stop shop" source for information on various conformity assessment issues.

Numerous federal agencies are engaged in conformity assessment activities. In addition, as part of its role mandated by the NTTAA, many agencies and federal programs utilize NIST support to help design and implement appropriate and effective conformity assessment programs. Some of the programs NIST supported during FY 2009 include:

- Health IT - NIST advised Health and Human Services' (HHS) Office of the National Coordinator for Health Information Technology (ONC) on the development of testing and certification programs for electronic health records technology. This consultative and collaborative engagement between ONC and NIST will continue during the implementation and operational phases of both temporary and permanent certification programs. In addition, NIST developed functional and conformance testing requirements, including methods and tools for the certification programs which will help to ensure compliance with technical requirements and the meaningful use of electronic health records technology.

- Smart Grid - The Energy Independence and Security Act of 2007 assigned NIST "primary responsibility to coordinate development of a framework that includes protocols and model standards for information management to achieve interoperability of smart grid devices and systems..." To fulfill this responsibility, NIST is working with stakeholders including industry and government to develop a plan for a testing and certification framework for Smart Grid related devices, systems, and processes, which will ensure interoperability and security under realistic operating conditions.

- Department of Homeland Security (DHS) Conformity Assessment Activities NIST continues its work with the Department of Homeland Security to develop the DHS Science and Technology standards and conformity assessment infrastructure as well as requirements, standards, testing protocols, and conformity assessment methods. For example, NIST's Radiation Physics Division and NIST's Technology Services are assisting with the implementation of a conformity assessment program for radiation detectors for DHS's Domestic Nuclear Detection Office including accreditation for testing laboratories whose testing will support the Graduated Rad/Nuc Detector Evaluation and Reporting (GRaDER) program. See http://www.dhs.gov/xres/programs/gc_1218637329931.shtm for additional information.

- National Toy Safety Initiative - NIST continues to provide technical assistance to the Consumer Product Safety Commission in their implementation of the Consumer Product Safety Improvement Act of 2008. CPSC successfully implemented their program to address toy safety issues by utilizing existing conformity assessment schemes. As a result, over 200 laboratories from 25 
countries were accredited by 17 different accreditation bodies during the fiscal year.

- DoD Environmental Laboratory Accreditation Program (DoD ELAP) - NIST's Technology Services staff provided assistance to the DoD Environmental Data Quality Workgroup (EDQW) to create a DoD-wide program to accredit laboratories that perform testing in support of DoD. This effort resulted in DOD EDQW implementing a program which utilizes internationally recognized accreditation bodies. http://www.navylabs.navy.mil/

- USGv6 - OMB Memorandum M-05-22 directed NIST to develop the technical infrastructure (standards and testing) necessary to support wide-scale adoption of IPv6 in the U.S. Government (USG). Upon detailed inspection of the state of the industry and the scope of IPv6 technology, NIST developed the USGv6 standard profile to assist agencies in the development of acquisition requirements for IPv6 products, and the USGv6 Test Program to provide the means to assess product compliance with such requirements. NIST accomplished these by using test laboratories which are accredited by internationally recognized laboratory accreditation bodies and allowing suppliers to issue a Supplier's Declaration of Conformity, based on the test reports, to assert their products' compliance. (http://w3.antd.nist.gov/usgv6/testing.html)

The full report of FY 2009 agency conformity assessment activities may be found in the Addendum to the Thirteenth Annual Report on Federal Use of Voluntary Consensus Standards and Conformity Assessment, available online at http://standards.gov/NTTAA/agency/index.cfm.

\section{0 - Evaluation of the Effectiveness of OMB Circular A-119}

During FY 2009, the majority of reporting agencies either had no comment on the effectiveness of OMB Circular A-119 or indicated that they found the Circular effective in helping them manage their standards development programs. However, several agencies did provide substantive comments concerning the Circular's effectiveness including recommended changes to the Circular, and these are presented below. ${ }^{2}$

- Department of Transportation (DOT) - DOT believes that Circular A-119 is working effectively. The use of voluntary standards provides efficiencies for regulatory agencies, and for regulated entities and industries. There continues to be a low volume of government-unique standards being used in lieu of voluntary consensus standards within DOT. However, DOT recommends that OMB Circular A-119 be revised to require NTTAA reporting only on instances of governmentunique standards being used in lieu of voluntary consensus standards, with the default position being that agencies are using voluntary consensus standards for regulatory work as much as possible. The Circular should continue the policy that there is no requirement to report on government-unique standards developed where

\footnotetext{
${ }^{2}$ It is within OMB's purview to consider and respond to these comments, as appropriate.
} 
a voluntary consensus standard is unavailable, per sections $6 \mathrm{~g}$ and $9 \mathrm{a}$ of the Circular.

- Department of Health and Human Services (HHS) - HHS's Center for Disease Control (CDC) works extensively with outside partner organizations for routine work. It would be very helpful if the Circular were extended towards building the federal standards development/implementation infrastructure with outlined horizontal and vertical structures, including infrastructures within federal organizations. Also, it would be to helpful to add associated reporting tasks (building of infrastructure).

- The Department of Defense (DoD) continues to recommend that the National Institute of Standards and Technology highlight in the NTTAA annual report to Congress examples of how government agencies are participating in the development of voluntary consensus standards and using these documents to meet requirements. The resources government entities commit to voluntary consensus standards development should not go unrecognized by Congress. Continuing support for Circular A-119 mandated activities is ensured when Congress is aware of the government's commitment to the Circular's tenets, as exemplified in the report's discussion of voluntary consensus standards participation.

The full text of agency comments may be found in the Addendum to the Thirteenth Annual Report on Federal Use of Voluntary Consensus Standards and Conformity Assessment, online at http://standards.gov/NTTAA/agency/index.cfm.

\section{0 - The Interagency Committee on Standards Policy (ICSP)}

During FY 2009, 57 individuals served on the ICSP, including agency Standards Executives, their alternates, NIST support staff, and representatives from OMB and the Executive Office of the President. The ICSP met three times in FY 2009, all of which were joint meetings with the American National Standards Institute's Government Member Forum. Information concerning the ICSP, including membership, charter, and meeting minutes, may be found online at http://standards.gov/icsp/query/index.cfm.

\section{0 - Success Stories: Examples from Federal Agencies}

Leveraging the private-sector standards development process for government purposes has been demonstrated to provide substantial resource savings for agencies and stakeholders throughout the Federal Government. Additionally, benefits flow to the private sector through Federal involvement and support of the voluntary consensus standards development process. Reports for FY 2009 show that agencies and affected stakeholders continue to realize benefits from Federal participation in the development and adoption of VCSs to support agency missions. Some examples of successes from the Fiscal Year 2009 reports are: 
Department of Energy (DOE) - DOE's Savannah River Site has implemented the transition from site standards to national codes and standards in order to comply with Public Law 104-113 and OMB A-119. This transition resulted in the reduction of the over 700 site-specific standards and guides to the present-day use of national codes and standards, supplemented by 12 site standards and 64 site guides. Also, DOE's Y-12 Site has several employees involved with the American Glovebox Society (AGS), writing and publishing documents related to gloveboxes. Y-12 has found that, by developing common requirements and expectations for gloveboxes and related equipment, vendors have been able to standardize their products so that features and components can be standardized for various customers. Gloveboxes used by the various DOE facilities, as well as industries such as pharmaceutical, biological, and other laboratories, all have unique requirements and are generally designed around a specific operation. However, by standardizing such features as glovebox windows and their attachment to gloveboxes, fabricators are able to standardize tooling and fabrication methods that reduce the cost for all customers. Another benefit to DOE is the use of proven, widely-applied standardized designs and practices. The Y-12 Site uses AGS standards to execute new designs. The Y12 Site also specifies AGS standards in procurement subcontracts for the glovebox fabricators to follow. One example of where this has been beneficial is in the standardization of requirements for welding related to glovebox fabrication. Before using AGS standards, vendors had to evaluate carefully the potentially unique Y-12 Site requirements and specifications related to glovebox fabrication. However, the Y-12 Site now specifies that welding shall be in accordance with AGS-G006-2005, "Standard of Practice for the Design and Fabrication of Nuclear-Application Gloveboxes." Vendors know exactly what they must do to meet the requirements of this standard.

Department of Health and Human Services (HHS) - HHS's SAMHSA (Substance Abuse and Mental Health Services) participated in the development of voluntary consensus standards for electronic health records (EHRs). An innovation that can reduce costs and improve the efficiency of data reporting, accountability and improved outcomes, EHRs support improvements in clinical care and foster improved coordination of care between the mental health and substance use specialty treatment sectors and general health care. In order to assure the capability for health information exchange while maintaining the appropriate confidentiality of records, SAMHSA joined voluntary consensus standards organizations to create technical options for patient consent in an e-health environment. Membership and participation in Health Level 7 and the Healthcare Information Technology Standards Panel allows SAMHSA to utilize a far wider range of expertise than allowed for by limited agency staff.

Nuclear Regulatory Commission (NRC) - One example of improved regulation achieved through standards participation is the extensive effort by two SDOs, the American Nuclear Society (ANS) and the American Society of Mechanical Engineers, (ASME), to develop a joint standard on quality of probabilistic risk assessment (PRA). NRC staff participated in writing the standard, a process that took over ten years. Industry participants involved in development of the standard commended the NRC staff for their support, based on work that NRC had already done on this topic. NRC has pointed to this standards development effort as a success story, in which potentially competing standards 
were avoided and consistent guidance was distilled into a single VCS. In addition, work is underway with standards development organizations to update voluntary consensus standards that may be applied to license renewal or new nuclear plant construction, including advanced reactor technologies. For example, NRC is partnering with ASME Standards Technology, LLC, to develop a roadmap for ASME standards changes that will support advanced reactor design, construction, operation, and maintenance. Benefits of NRC staff participation in voluntary consensus standards development include cost savings, improved efficiency and transparency, and high technical quality of regulatory requirements.

\section{0 - Summary and Conclusions}

As of FY 2009, 13 years since the start of the NTTAA reporting requirement, Federal agencies indicate that they use 46 government-unique standards in lieu of voluntary consensus standards. This small inventory reflects a real and continuing reliance on voluntary consensus standards. The NTTAA has successfully encouraged agencies to look first to voluntary consensus standards and to engage with the private sector standards system for solutions to government needs, rather than to develop governmentunique standards unnecessarily.

Guided by the NTTAA and OMB A-119, NIST continues to assist Federal agencies and their stakeholders with standards and conformity assessment information, program support, guidance and policy concerns. NIST hosts the portal http://standards.gov, which provides a "one-stop" e-government location for information related to Federal use of voluntary consensus standards and federal engagement in the standards development process. This portal offers background, materials, useful links, and search tools for locating information about the use of standards in government, including the searchable Standards Incorporated by Reference database. The website enables NIST to provide ongoing, practical guidance, tools, and information needed by agencies to implement the NTTAA successfully as well as an electronic means to report standards activities as required by the NTTAA and OMB Circular A-119. In addition, NIST is working with agency standards executives and OMB to integrate standards participation and use more directly into the missions, decision-making processes, operating procedures, and strategic goals of Federal agencies. This report fulfills the annual reporting requirements of both the NTTAA and OMB Circular. 


\section{Appendix A -- FY 2009 List of Reporting Federal Agencies}

\begin{tabular}{|c|c|c|}
\hline Agency & Acronym & Standards Program Website \\
\hline Department of Agriculture & USDA & $*$ \\
\hline Department of Commerce & DOC & http://ts.nist.gov/commerce/ \\
\hline Department of Defense & DoD & http://www.dsp.dla.mil \\
\hline Department of Energy & DOE & http://www.hss.energy.gov/nuclearsafety/ns/techstds/ \\
\hline Department of Education & ED & * \\
\hline $\begin{array}{l}\text { Department of Health and } \\
\text { Human Services }\end{array}$ & HHS & $\begin{array}{l}\text { FDA Center for Devices and Radiological Health: } \\
\text { http://www.cdrh.fda.gov/science/standards/constand.htm }\end{array}$ \\
\hline $\begin{array}{l}\text { Department of Homeland } \\
\text { Security }\end{array}$ & DHS & http://www.dhs.gov/xfrstresp/standards/ \\
\hline $\begin{array}{l}\text { Department of Housing and } \\
\text { Urban Development }\end{array}$ & HUD & http://www.hud.gov/offices/hsg/sfh/mps/mpshome.cfm \\
\hline Department of the Interior & DOI & $*$ \\
\hline Department of Justice & DOJ & $\begin{array}{l}\text { http://www.ojp.gov/nij/topics/technology/standards- } \\
\text { development.htm }\end{array}$ \\
\hline Department of Labor & $\mathrm{DOL}$ & * \\
\hline Department of State & DOS & $*$ \\
\hline Department of Transportation & DOT & $\begin{array}{l}\text { Various - see DOT's report, available via } \\
\text { http://standards.gov/NTTAA/agency/index.cfm }\end{array}$ \\
\hline Department of the Treasury & TRES & http://www.treas.gov/offices/international-affairs/standards/ \\
\hline Environmental Protection Agency & EPA & $\begin{array}{l}\text { http://www.epa.gov/p2/pubs/programs/voluntary.htm } \\
\text { (program specific) }\end{array}$ \\
\hline General Services Administration & GSA & $\begin{array}{l}\text { from http://www.gsa.gov, click on "About GSA," then } \\
\text { "Reference," then "Supply Standards" }\end{array}$ \\
\hline $\begin{array}{l}\text { National Archives and Records } \\
\text { Administration }\end{array}$ & NARA & $*$ \\
\hline $\begin{array}{l}\text { National Aeronautics and Space } \\
\text { Administration }\end{array}$ & NASA & http://standards.nasa.gov \\
\hline National Science Foundation & NSF & $*$ \\
\hline $\begin{array}{l}\text { Consumer Product Safety } \\
\text { Commission }\end{array}$ & CPSC & http://www.cpsc.gov/volstd/standards.html \\
\hline $\begin{array}{l}\text { Federal Communications } \\
\text { Commission }\end{array}$ & FCC & * \\
\hline Federal Trade Commission & FTC & $*$ \\
\hline Nuclear Regulatory Commission & NRC & http://www.nrc.gov/about-nrc/regulatory/standards-dev.html \\
\hline Government Printing Office & GPO & http://www.gpo.gov/customers/vol11.htm \\
\hline Access Board & ACCESS & http://www.access-board.gov/gs.htm \\
\hline
\end{tabular}

*Not available or not reported 
Appendix B -- FY 2009 Federal Agency Information on Participation/Adoption of Voluntary Standards Activities Required by OMB Circular A-119

\begin{tabular}{|c|c|c|c|c|c|}
\hline Agency & $\begin{array}{l}\text { Government- } \\
\text { unique standards } \\
\text { used in lieu of } \\
\text { voluntary } \\
\text { consensus } \\
\text { standards }\end{array}$ & $\begin{array}{c}\text { Voluntary } \\
\text { consensus } \\
\text { standards } \\
\text { substituted for } \\
\text { government- } \\
\text { unique standards }\end{array}$ & $\begin{array}{c}\text { Voluntary } \\
\text { consensus } \\
\text { standards } \\
\text { used this } \\
\text { year } \\
\text { (new uses) }\end{array}$ & $\begin{array}{c}\text { Employee } \\
\text { participation } \\
\text { in voluntary } \\
\text { consensus } \\
\text { standards } \\
\text { bodies }\end{array}$ & $\begin{array}{c}\text { Voluntary } \\
\text { consensus } \\
\text { standards } \\
\text { bodies with } \\
\text { agency } \\
\text { participation }\end{array}$ \\
\hline USDA & 1 & 0 & 0 & 123 & 38 \\
\hline DOC & 0 & 0 & 0 & 494 & 109 \\
\hline DoD & $*$ & 112 & 77 & na & 122 \\
\hline DOE & 0 & 0 & 146 & 449 & 89 \\
\hline ED & 0 & 0 & 0 & 24 & 4 \\
\hline HHS & 1 & 0 & 18 & 1150 & 192 \\
\hline DHS & 0 & 0 & 62 & 212 & 58 \\
\hline HUD & 2 & 0 & 0 & 4 & 5 \\
\hline DOI & 0 & 0 & 2 & 166 & 83 \\
\hline DOJ & 0 & 0 & 0 & 1 & 0 \\
\hline DOL & 9 & 0 & 0 & 38 & 19 \\
\hline DOS & 0 & 0 & 0 & 9 & 1 \\
\hline DOT & 3 & 0 & 4 & 162 & 56 \\
\hline TRES & 0 & 0 & 1 & 0 & 0 \\
\hline EPA & 23 & 0 & 49 & 65 & $* * *$ \\
\hline GSA & 3 & 0 & 0 & 19 & 21 \\
\hline NARA & 1 & 0 & 0 & 16 & 12 \\
\hline NASA & $*$ & 0 & 0 & 124 & 18 \\
\hline NSF & 0 & 0 & 0 & 10 & 5 \\
\hline CPSC & 2 & 0 & 2 & 22 & 8 \\
\hline FCC & 0 & 0 & 0 & 28 & 13 \\
\hline FTC & 0 & 0 & 0 & 0 & 0 \\
\hline NRC & 0 & 0 & 2 & 181 & 15 \\
\hline GPO & 0 & 0 & 0 & 10 & 0 \\
\hline ACCESS & 1 & 0 & 0 & 9 & 6 \\
\hline Totals & 46 & 112 & 363 & 3316 & $* *$ \\
\hline
\end{tabular}

*Agencies reporting on a categorical basis per OMB Circular A-119, Section 12.

** Total not provided. Total would result in multiple counting due to participation in standards bodies by two or more Federal agencies.

*** Data not submitted. 
Appendix C -- FY 2009 Government-Unique Standards used in lieu of Voluntary Consensus Standards

\begin{tabular}{|c|c|l|}
\hline 1 & Agency: & Department of Labor (DOL) \\
\cline { 2 - 3 } & $\begin{array}{c}\text { Government-Unique } \\
\text { Standard: }\end{array}$ & $\begin{array}{l}\text { Longshoring and Marine Terminals; Vertical Tandem } \\
\text { Lifts [Incorporated: 2009] }\end{array}$ \\
\hline $\begin{array}{c}\text { Voluntary Standard: } \\
\text { ISO 668:1995 - Series 1 freight containers--Classification, } \\
\text { dimensions and ratings. } \\
\text { ISO } 1161: 1984 \text { - Series } 1 \text { freight containers--Corner fittings-- } \\
\text { Specification. } \\
\text { ISO } 1161: 1984 / \text { Cor. 1:1990 - Technical corrigendum 1:1990 to } \\
\text { ISO 1161:1984. } \\
\text { ISO 1496-1:1990 - Series 1 freight containers-- }\end{array}$ \\
\hline $\begin{array}{l}\text { Reveral voluntary consensus standards were relied upon for } \\
\text { the various provisions in the final rule, however, no single VCS } \\
\text { is available to cover all the workplace applications that are } \\
\text { addressed by OSHA. The Agency believes that it would be less } \\
\text { burdensome for the regulated community to use one OSHA } \\
\text { standard rather than purchase and use the nine individual } \\
\text { consensus standards used in this rule. }\end{array}$ \\
\hline
\end{tabular}

